\title{
PHYSICO-CHEMICAL, PHYTOCHEMICAL AND ANTIMICROBIAL ANALYSIS OF BLACK CUMIN AND FENUGEEK SEED OILS
}

\author{
Olorunsola Morayo Adejuwon \\ Department of Science Technology, \\ Federal Polytechnic, Ado-Ekiti, Nigeria. \\ Funmilola Ayodele Ishaya, \\ Department of Science Technology, \\ Federal Polytechnic, Ado-Ekiti, Nigeria.
}

\author{
Kolawole Omobusuyimi Matthew \\ Department of Food Technology, \\ Federal Polytechnic, Ado-Ekiti, Nigeria. \\ Aliyu Ahmad Warra, \\ Centre for Entrepreneurial Development, \\ Federal University, Gusau, Nigeria.
}

\author{
Adejoju Omodolapo Adedara \\ Department of Chemistry, \\ Federal University of Technology, \\ PMB 704, Akure, Nigeria.
}

\begin{abstract}
Plants have been used over the time as a basis of traditional cure for mankind. Plant oil components are effective against pathogenic bacteria. Lately, the utilization of phytomedicine has been increased enormously for treatment of numerous ailments because they are easily accessible and cheap. In this study, the physicochemical properties, phytochemicals constituents and antimicrobial activities of oil extracted from black cumin and Fenugeek were evaluated, also Soaps tablets were formulated using the extracted oil through cold saponification process and the activities of the soap against Staphylococcus aureus, Streptococcus pyogenes, Escherichia coli and Salmonella typhi were investigated. The result of the Physicochemical analysis showed refractive indices of 1.4657 and 1.4730 , specific gravity of 1.349 and $1.366 \mathrm{~g} / \mathrm{cm} 3$, peroxide value of 7.03 and $10.06 \mathrm{meq} \mathrm{O2/kg}$, Saponification value (mgKOH/g) of 192.3 and 183.3, Free fatty acid (\% oleic acid) of 7.24 and 12.4 and unsaponifiable matter of 1.2 and $1.6 \%$ for black cumin and Fenugeek seed oil respectively. Bioactive constituents present in both seed oils were alkaloids, flavonoids, saponins, tannins, and phenolic compounds which are responsible their antibacterial activities. The results showed that soap prepared with Fenugeek seed oil have the highest activity against all bacterial strains tested in this study. However, black cumin oil is active against all strains of bacteria only at higher concentration $(200 \mathrm{mg} / \mathrm{L})$.
\end{abstract}

Black cumin and Fenugeek seed oils are highly effective against skin bacteria. The oils can be used as natural antibacterial in industries for production soaps.
Keywords: Saponification, Zone of inhibition, Seed oils, Isolation

\section{INTRODUCTION}

The development of bio cosmetics products from natural sources is now being encouraged worldwide because it is estimated that only $15 \%$ out of the 300,000 herbal species have been explored for therapeutic purpose. Among several medicinal plants, Nigella sativa L. (Ranunculaceae) and Fenugreek seed (foenumgraecum) have been considered among the most treasured antioxidant-rich herb, various scientific studies are ongoing to prove the traditionally uses of these plant seeds $[1,2]$.

Black cumin (Nigella sativa) belongs to the Ranunnclaceae family it is often called as "Haba al-barakah" meaning seeds of blessings. It has been used as a medicinal plant across the globe e.g for remediation of health in folklore medicine for treating various health disorders [3]. Black cumin seeds contain significant levels of iron, copper, zinc, phosphorus, calcium, thiamin, niacin, pyridoxine, and folic acid [2]. Research have shown that black cumin seed contain $26-34 \%$ fixed oil which are linoleic acid (64.6\%) and palmitic acid (20.4\%). The seed oil comprises $0.4 \%-2.5 \%$ essential oil [4,5]. According to Erkan et al 2008 [6] the plant seed have the potential of being used as natural sources of antioxidants as it contain flavonoids, tannins and phenolic acids etc, the seed oil also contains thymoquinone which is the major component of the essential oil and is the most bioactive compound with wide range of therapeutic benefits, it is effective against cardiovascular disorders, neurological and mental illness, diabetes, and 


\section{International Journal of Engineering Applied Sciences and Technology, 2020 \\ Vol. 5, Issue 3, ISSN No. 2455-2143, Pages 124-128 \\ Published Online July 2020 in IJEAST (http://www.ijeast.com)}

infertility as well as various infectious diseases caused by fungal or bacterial, parasitic, and viral infections [7].Black cumin seeds oil extracts have also been proven to possess antioxidant, anticancer, analgesic, anti-inflammatory and antimicrobial activities [8].

Fenugreek is a legume and it belongs to the plant family of Fabaceae. Fenugreek seeds are commonly used as spices worldwide, its leaves can be eaten as green vegetables in the daily diet. Fenugreek Leaves and seeds have been used extensively for medicinal purposes [9]. Fenugreek is reported to have anti-diabetic, anti-fertility, anticancer [10], antimicrobial, anti-parasitic and hypo cholesterolaemic effects [11]. The bioactive constituents of seeds of Fenugreek such as volatile oils, flavonoid, alkaloid, and phenol were reported to have been responsible for its antimicrobial activity [12]. Based on the studies carried out on fenugreek and black cumin, report shows that the seed oil of these plant possesses strong antibacterial activity [13]. However, few reports are available on the use of these seed oils as antibacterial agent in soap production. Hence, this present research was conducted out to determine the antibacterial activity of soap prepared with black cumin and fenugreek seed oils against the selected strains of bacteria.

\section{MATERIALS AND METHODS}

Black cumin and Fenugeek seeds were purchased from the market. $50 \mathrm{~g}$ each of the seeds were weighed and placed at shaded area to prevent it from being exposed to sunlight in order to avoid evaporation of active constituent such as phenol, the seeds were allowed to dry at room temperature for 7 days. After 7 days the seeds were crushed into powdered form using the crusher. The powdered sample was put into a porous thimble and placed in a Soxhlet extractor and then extracted with nhexane (GG-17, SHUNIU; with boiling point of $65^{\circ} \mathrm{C}$ ) as extracting solvent for 6 hours repeatedly until required quantity was obtained. The solvent in extracted solution was removed using a water bath at $70^{\circ} \mathrm{C}$ and the extracted plant oil was stored in refrigerator at $4^{0} \mathrm{C}$ to prevent oil degradation prior further analysis. The oil yield was calculated using equation 1

Oil yield $(\%)=V / W \times 100=$
$\frac{\text { Amount of oil extracted in } \mathrm{mL}}{\text { Weight of dry sample used in gram }} \times 100$

\section{A. Physicochemical Analyses of the Black Cumin oil samples.}

The specific gravity and refractive index of the oils were determined as described by Pearson [14]. Peroxide value was determined as described by AOAC [15] using titration method. Saponification value, free fatty acid value, and percentage of unsaponifiable matter of the seed oils were determined according to AOCS [15].

\section{B. Phytochemical Analysis}

The phytochemical analysis was evaluated with different reagents as described by Bourgo et al. [16]; Mbatchou et al. [17] and Kazemi [7] to determines the existence or nonexistence of saponins, alkaloids, flavonoids, glycosides and tannins in seed oil extracts

\section{Test for tannins}

Five milliliter $(5 \mathrm{ml})$ of the oil extract was measured into a test tube and then $1 \mathrm{ml}$ of $5 \%$ ferric chloride solution was added, the mixture was allowed to react for a few seconds, a dark green color was observed indicating the presence of tannins.

\section{Test for saponins}

One milliliter $(1 \mathrm{ml})$ of oil extract was diluted with $5 \mathrm{ml}$ of distilled water. The mixture was shaken in the test tube for 15 min the formation of stable foam confirmed the presence of saponins.

\section{E. Test for flavonoids}

Few drops of 10 percent Sodium hydroxide $(10 \% \mathrm{NaOH})$ was added to $3 \mathrm{ml}$ of the oil extract in a test tube, the mixture was warmed and 4 drops of dilute $\mathrm{HCl}$ was added to the mixture. An intense yellow color was formed which turned colorless on addition of few drops of dilute acid indicating the presence of flavonoids.

\section{F. Test for alkaloids}

Two milliliter $(2 \mathrm{ml})$ of oil extracts was warmed with $4.0 \mathrm{ml}$ of $2.0 \% \mathrm{HCl}$ for 3 minutes. The solution was filtered and few drops of Dragendorff's reagent were added to the acidic mixture. There was appearance of Orange red precipitate which indicated the presence of alkaloids.

\section{G. Test for steroids}

Salkowaski test was used to determine the presence of steroids in the plant oil extracts. $2 \mathrm{ml}$ of chloroform was mixed with $2 \mathrm{ml}$ of concentrated sulphuric acid, then $8 \mathrm{ml}$ of oil extract was added to the solution. The mixture was shaken for a few seconds and then a red color was observed at the interphase, at the chloroform layer; which confirmed the presence of steroids in the oil extracts.

\section{H. Test for terpenoids}

Two milliliter ( $2 \mathrm{ml}$ ) of oil extracts was mixed with $3 \mathrm{ml}$ of chloroform, $1 \mathrm{ml}$ of concentrated $\mathrm{H}_{2} \mathrm{SO}_{4}$ was carefully added to the mixture to form a layer. A reddish-brown coloration was formed at the interface this indicates the presence of terpenoids.

\section{Test for Phenols}

One milliliter $(1 \mathrm{ml})$ of the oil extract was measured into a test tube, few drops of $10.0 \%$ Lead acetate was added to the oil. White precipitate was form which confirmed the presence of phenols. 


\section{J. Test for cyanogenic glycosides}

Two milliliter $(2 \mathrm{ml})$ of distilled water was added to $1 \mathrm{ml}$ of the plant oil in a test tube, then 6 drops of chloroform were added and the mixture stirred. The test tube was stoppered with a cork containing a strip of picrate-impregnated paper hanging down from the stopper, and incubated at ambient temperature for $2 \mathrm{~h}$. A color change of the paper was observed to confirm the presence of cyanogenic glycosides. No color change was observed after 48 hours which indicated that plant oils does not contain cyanogenic glycosides.

\section{K. Soap Preparation}

The soap was produced using cold saponification process. The plant seed oils were mixed with 100 grams of sodium hydroxide in $500 \mathrm{~mL}$ of distilled water. The alkaline solution was mixed with plant seed oils in the ratio $2: 2 \mathrm{v} / \mathrm{v}$. The mixtures were then stirred vigorously until the reaction reach equilibrium i.e. until soaps were formed at room temperature. The mixtures were then poured into the mold and allowed to cure for $48 \mathrm{~h}$.

Antibacterial Activity Screening

\section{Test Organisms}

The test organisms used for antibacterial activity of soap prepared from the plant oil were, Streptococcus pyogenes, Staphylococcus aureus, Salmonella typhi and Escherichia coli. The organisms were procured from the Federal University Gusau. Identified as described by Cheesbrough [18].

\section{Maintenance of Bacterial Cultures}

The bacterial cultures were sub-cultured and maintained on Nutrient agar slants and stored in refrigerator at $4{ }^{\circ} \mathrm{C}$

\section{N. Preparation of Inoculum}

The suspension of each organism was prepared by picking a fresh and pure colony of the test organism from an overnight culture ( 18 hours of incubation at $37^{\circ} \mathrm{C}$ ) with a sterile wire loop and suspended in $10 \mathrm{~mL}$ of nutrient agar to form a density of approximately $1.0 \times 10^{8}$, until a moderate turbidity was developed. This was carried out by matching the suspension with 0.5 McFarland turbidity standards (NCCL) [17].

\section{O. Determination of Antibacterial of the Formulated Soap}

Antimicrobial activity screening for the antimicrobial activity of prepared soap were determined according Aqil and Ahmad [13] and Abdel-massih et al [19] using agar well diffusion method, which is generally used to determine the antibacterial activity of microbial extracts. The test bacterial isolates were inoculated on to a plate surface by using a sterile swab to spread microbial inoculum over the entire agar surface, Then, $6 \mathrm{~mm}$ diameter hole was punched aseptically with a sterile cork borer, and the Soaps prepared with plant in three different concentrations $(100 \mathrm{mg}, 150 \mathrm{mg}$ and $200 \mathrm{mg}$ ) were introduced into the well. Then, agar plates were allowed to stand for $30 \mathrm{~min}$ and then incubated at $37^{\circ} \mathrm{C}$ for $24 \mathrm{~h}$. The antibacterial activity was determined by measuring the diameter of the zone of inhibition (in $\mathrm{mm}$ ) and compared with the standard antibiotics (Chloramphenicol).

\section{RESULTS AND DISCUSSION}

Table 1. Physicochemical analysis of the seed oils

\begin{tabular}{|l|l|l|}
\hline Parameter & Black cumin & Fenugreek \\
\hline Acid value (mg/KOH/g) & 12.971 & 6.413 \\
\hline $\begin{array}{l}\text { Saponification } \\
\text { value(mg/KOH/g) }\end{array}$ & 192.290 & 183.321 \\
\hline Free fatty acid (\% oleic) & 7.244 & 12.432 \\
\hline $\begin{array}{l}\text { Peroxide Value (meq/O } / 2 \\
\text { Kg }\end{array}$ & 7.03 & 10.06 \\
\hline $\begin{array}{l}\text { Unsaponifiable matter } \\
(\%)\end{array}$ & 1.2 & 1.6 \\
\hline Specific gravity (g/cm3) & 1.349 & 1.366 \\
\hline Refractive index & 1.466 & 1.473 \\
\hline Percentage yield (\%) & 30.32 & 35.26 \\
\hline
\end{tabular}

A. Physicochemical analysis of the seed oils

The result of the Physicochemical analysis showed refractive indices of 1.4657 and 1.4730 , specific gravity of 1.349 and $1.366 \mathrm{~g} / \mathrm{cm} 3$, peroxide value of 7.03 and $10.06 \mathrm{meq} \mathrm{O} / \mathrm{kg}$, Saponification value $(\mathrm{mg} \mathrm{KOH} / \mathrm{g})$ of 192.3 and 183.3, Free fatty acid (\% oleic acid) of 7.24 and 12.4 and unsaponifiable matter of 1.2 and $1.6 \%$ for Black cumin and Fenugeek seed oils respectively. Refractive index is similar to those obtained by Sulieman et al. [2] for fenugeek seed oil. According to Sultan et al. [1], Refractive index and specific gravity gives a quantitative estimation of oxidative stability of fats and oils. The peroxide value obtained is comparable with those obtained by Cheikh-Rouhou et al [20]. Peroxide value gives information on rancidity of fat and oils. The value obtained showed that is not rancid. The saponification value and percentage of unsaponifiable is in concordance with values obtained by Atta [21]: Abbas et al. [22]: Sulieman et al. 2008 and CheikhRouhou et al. [20].

Table 2. Phytochemical analysis

\begin{tabular}{|l|l|l|}
\hline PHYTOCHEMICALS & Black cumin oil & Fenugreek oil \\
\hline Tannins & + & + \\
\hline Saponins & + & + \\
\hline
\end{tabular}




\begin{tabular}{|l|l|l|}
\hline Flavonoids & + & + \\
\hline Alkaloids & + & + \\
\hline Steroids & + & + \\
\hline Terpenoids & + & + \\
\hline Phenols & + & + \\
\hline Cyanogenic glycosides & - & - \\
\hline
\end{tabular}

inhibition was noticed against Streptococcus pyogenes $(27 \mathrm{~mm})$ followed by Escherichia coli and Salmonella typhi $(26 \mathrm{~mm})$ and then Staphylococcus aureus ( $25 \mathrm{~mm}$ ) which falls within the range of susceptible inhibition zone [27].The zone observed was compared with standard antibiotic chloramphenicol (Chl).

Table 4: Zone of inhibition of bacteria strains against soap formulated with Fenugreek seed (foenum graecum)

\begin{tabular}{|l|l|l|l|l|}
\cline { 2 - 5 } \multicolumn{1}{c|}{} & \multicolumn{4}{c|}{ Zone of inhibition (mm) } \\
\hline $\begin{array}{l}\text { Soap } \\
\text { Concentration }\end{array}$ & E. coli & S. typhi & S. aureus & S. pyogenes \\
\hline $100 \mathrm{mg} / \mathrm{mL}$ & $\begin{array}{l}30 \\
\mathrm{~mm}\end{array}$ & $14 \mathrm{~mm}$ & $24 \mathrm{~mm}$ & $10 \mathrm{~mm}$ \\
\hline $150 \mathrm{mg} / \mathrm{mL}$ & $\begin{array}{l}35 \\
\mathrm{~mm}\end{array}$ & $16 \mathrm{~mm}$ & $33 \mathrm{~mm}$ & $15 \mathrm{~mm}$ \\
\hline $200 \mathrm{mg} / \mathrm{mL}$ & $\begin{array}{l}37 \\
\mathrm{~mm}\end{array}$ & $20 \mathrm{~mm}$ & $36 \mathrm{~mm}$ & $18 \mathrm{~mm}$ \\
& & & & \\
\hline
\end{tabular}

\section{B. Phytochemical analysis}

Table 2 shows the results of phytochemical analysis of seed oils, the result indicates that fenugreek seed oil and black cumin seed oil consist of Tannins, flavonoids, alkaloids, terpenoids, saponins, and steroids. The presence of tannins is most expected to be accountable for the antioxidant and anti-inflammatory properties of the seed oils. Additional therapeutic properties could be due to the presence of alkaloids. Fenugreek seed oil and black cumin seed oil samples do not contain cyanogenic glycosides which make them safe to use. The result obtained is similar to those obtained by Mraihi et al. [23] and Ahmad et al. [24] for the same seed oil.

Table 3: Zone of inhibition of bacteria strains against soap formulated with Black cumin oil (Nigella sativa)

\begin{tabular}{|l|l|l|l|l|}
\cline { 2 - 5 } \multicolumn{1}{c|}{} & \multicolumn{4}{c|}{ Zone of inhibition (mm) } \\
\cline { 2 - 5 } \multicolumn{1}{c|}{} & \multicolumn{4}{c|}{$150 \mu \mathrm{L}$ of each soap concentration used } \\
\hline $\begin{array}{l}\text { Soap } \\
\text { Concentration }\end{array}$ & E. coli & S. typhi & S. aureus & S. pyogenes \\
\hline $100 \mathrm{mg} / \mathrm{mL}$ & - & $17 \mathrm{~mm}$ & $11 \mathrm{~mm}$ & - \\
\hline $150 \mathrm{mg} / \mathrm{mL}$ & $\begin{array}{l}22 \\
\mathrm{~mm}\end{array}$ & $21 \mathrm{~mm}$ & $18 \mathrm{~mm}$ & $12 \mathrm{~mm}$ \\
\hline $200 \mathrm{mg} / \mathrm{mL}$ & $\begin{array}{l}26 \\
\mathrm{~mm}\end{array}$ & $26 \mathrm{~mm}$ & $25 \mathrm{~mm}$ & $27 \mathrm{~mm}$ \\
& & & & \\
\hline
\end{tabular}

\section{Antibacterial activity}

The results of the antibacterial activity of different concentrations (100 mg, $150 \mathrm{mg}$ and $200 \mathrm{mg}$ ) of soaps prepared with Black cumin oil (Nigella sativa) examined against bacterial pathogens were shown in Table 3 . At $100 \mathrm{mg} / \mathrm{mL}$, antibacterial activity was only noticed in salmonella typhi and Staphylococcus aureus. No antibacterial activity against Streptococcus pyogenes and Escherichia Coli. At $150 \mathrm{mg} / \mathrm{mL}$, zone of inhibition was recorded against all the test organisms. However, antibacterial activity was also observed against all bacteria pathogens studied at $200 \mathrm{mg} / \mathrm{mL}$ and maximum zone of

Table 4 shows antibacterial activity of different concentrations (100 mg, $150 \mathrm{mg}$ and $200 \mathrm{mg}$ ) of soap prepared with Fenugreek seed (foenum graecum) against bacterial pathogens. Antibacterial activities were noticed against all the test organisms at all concentrations used in this study. The prepared soap displayed a higher inhibition zone against $\mathrm{E}$ coli and $\mathrm{S}$. aureus. Minimum zone of inhibition was noticed in Streptococcus pyogenes $(10 \mathrm{~mm})$, no zone of inhibition was seen in blind control. The result obtained is in concordance with those reported by Wagate et al. [25]; Hasan et al. [26] and Maryam et al. [27]. The result implies that the soap is more active against Escherichia coli and S. aureus than other test organism used in this study.

\section{CONCLUSION}

Soaps prepared from Fenugeek seed oil and black cumin seed oil have been proven to be effective against all the bacteria strain used in this study due to the presence of bioactive compounds such as alkaloids, flavonoids, saponins, tannins, and phenolic compounds. Soap prepared with Fenugeek seed oil have the highest activity against all bacterial strains tested in this study. However, black cumin oil is active against all strains of bacteria only at higher concentration $(200 \mathrm{mg} / \mathrm{L})$. Soaps prepared with plant seed oil are now being considered as an excellent alternative to eliminate the spread of virus and bacterial pathogens. This study recommends the incorporation of plant oil into soap production in order to stop the spread of microorganisms. 


\section{ACKNOWLEDGEMENTS}

The authors appreciate the Centre for Research, Innovation and Development (CRID), Federal Polytechnic, Ado-Ekiti, Nigeria, for supporting this research work through Tetfund Institution Based Research grant (IBR). The authors also thank Dr. Kunle Adesina, Director of CRID for his kind gesture.

\section{REFERENCES}

[1] Sultan, M.T., Butt, M.S., Anjum, F.M., Jamil, A., Akhtar, S. and Nasir, M. (2009). Nutritional profile of indigenous cultivar of black cumin seeds and antioxidant potential of its fixed and essential oil: Pakistan. Journal of Botany. 41(3): 1321-1330.

[2] Sulieman, A., Ahmed, H. and Abdelrahim A. (2008). The Chemical Composition of Fenugreek (Trigonella Foenum graceum L) and the Antimicrobial Properties of its Seed Oil: Gezira Journal of Engineering and Applied Sciences. 3 (2), 52-71

[3] Hajra, N. (2011). Nigella sativa: the miraculous herb: Pakistan Journal of Biochemistry and Molecular Biology. 44 (1), 44-48.

[4] Pant,K.S., Koshla,V., Kumar,D.and Gairola, G. (2006). Seed oil content variation in Jatrophacurcas Linn.in different altitudinal ranges and site conditions in H.P. India. Lyonia, 11, 31-34.

[5] Malecka, M. (2002). Antioxidant properties of the unsaponifiable matter isolated from tomato seeds, oat grains and wheat germ oil. Food Chemistry. 79: 327-330

[6] Erkan N, Ayranci G, Ayranci E (2008). Antioxidant activities of rosemary (Rosmarinus Officinalis L.) extract, blackseed (Nigella sativa L.) essential oil, carnosic acid, rosmarinic acid and sesamol. Food Chem, 110:76-82.

[7] Kazemi M. (2014). Phytochemical composition, antioxidant, anti-inflammatory and antimicrobial activity of Nigella sativa L essential oil: Journal of Essential Oil-Bearing Plants. 17(5): 1002-1100.

[8] Gali-Muhtasib H, El-Najjar N and Schneider-Stock R (2006) The medicinal Potential of black seed (Nigella sativa) and its components. Advances in Phytomedicine, 2, 133- 153.

[9] Basch, E, Ulbricht., C., Kuo, G., Szaparyp, P and Smith, M. (2003). Therapeutic applications of fenugree : Alt. Med. Rev. 8 (1): 20-27.

[10] Mazza, G. and Di-Tommaso, D. (2002). Volatile constituents of Sicilian fenugreek (Trigonellafoenum-graecum L.) seeds. Sciences-des Aliments (France). 22(3): 249-264

[11] Pande, K. K., Pande, L., Pande, B., Pujari, A., Sah, P., and Sah, S. (2011). Limonene dominates the Photochemistry of Trigonella foenum-graceumin Nature.Nature and Science.9(5):17-20.

[12] Fraenkel, and Gottfried, S. (2007). The raison of secondary plant substances. Science129 (3361):1466-.1470.
[13] Aqil, F. and Ahmad I. (2003). Broad-spectrum antibacterial and antifungal properties of certain traditionally used Indian medicinal plants. World Journal of Microbiology and Biotechnology.19(6):653-657.

[14] Pearson, D. (1991). In Pearson's Composition and Analysis of Foods, edited by Kirk, R.S. \& Sawyer, R. UK: Longman Scientific \& Technical. p. 624.

[15] Official Methods of Analysis of the Association of Official Analytical Chemists, AOAC. (1998); 16th Edn.Gaithersburg, USA

[16] Bourgou S, Pichette A, Marzouk B and Legault J. (2016). Antioxidant, anti-inflammatory, anticancer a antibacterial activities of extracts from Nigella sativa (Black Cumin) plant parts. J Food Biochem. 36: 539-46.

[17] Mbatchou, V C., Kosoono, I (2012). Aphrodisiac activity of oils from Anacardium OccidentaleL. Seeds and seed shells. Phytopharmacology. 2(1): 81-91.

[18] Cheesbrough, M. (2006). District Laboratory Practice in Tropical Countries (2nd Edition). London English Language Book. Society. pp. 100-14.

[19] Abdel-massih R, Abdou E, Baydoun E, Daoud Z. (2010). Antibacterial Activity of the Extracts Obtained from Rosmarinus officinalis, Origanummajorana, and Trigonellafoenum-graecum on Highly Drug- Resistant GramNegative Bacilli. Journal of Botany. 3(80):52-59. 17.

[20] Cheikh-Rouhou, S., Besbes, S., Hentati, B., Blecker, C., Deroanne, C. \&Attia, H. (2007). N. sativa L.: Chemical composition and physicochemical characteristics of lipid fraction. Food Chem. 101(2): 673-681

[21] Atta, M.B. 2003. Some characteristics of nigella (Nigella sativaL.) seed cultivated in Egypt and its lipid profile. Journal of Food Chemistry 83: 63-68.

[22] Applequist WL, Avula B, Schaneberg BT, Wang YH, Khan IA. (2006). Anal: J Food Comp. 19:606.

[23] Mraihi F, Journi M, Chérif JK and Trabelsi-Ayadi M. (2013). Characterization of three Nigella sativa L. crude oil species, measures of their antioxidant activity by DPPH: Journal of Biologically Active Products from Nature. 3(3): 208215.

[24] Ahmad A, Husain A, Mujeeb M, Khan SA, Najmi AK, Siddique NA, Damanhouri ZA and Anwar F. (2013). review on the therapeutic potential of Nigella sativa: a miracle herb: Asian Pac J Trop Biomed. 3: 337-52

[25] Wagate CG, Mbaria J.M, Gakuya D. W., Nanyingi MO, Kareru P.G, Kimani N, Nduhiu G and Macharia J.K (2010). Screening of Kenyan medicinal plant for antibacteria activity: Phytother Res. Doi; 10.1002.

[26] Hasan N. A., Nawahwi M. Z. and Malek H. A (2013). Antimicrobial activity of nigella sativa seed extract:Sains Malaysiana.42(2):143-147

[27] Maryam A.-J., Fatimah A.-A., Ebtesam A.-K., Abdulrahman A.-S., Ineta B. (2016). In-vitro studies on the effect of Nigella sativa Linn., seed oil extract on Multidrug Resistant Gram positive and Gram negative bacteria: Journal of Medicinal Plants.4(2):195-199. 